\title{
The Role of Jigsaw IV based on WhatsApp in Enhancing English Vocabulary among EFL Major Students
}

\author{
Rabea Ali \\ Lecturer of Applied linguistics (ELT) \\ Department of English language and translation \\ College of Sciences and Arts \\ Qassim University \\ Kingdom of Saudi Arabia
}

\begin{abstract}
The availability and the use of WhatsApp are increasingly widespread among Arab EFL learners. The current study aimed to investigate the role of Jigsaw IV based on WhatsApp in improving English vocabulary among Saudi university students. The participants of the study were 40 students. They were divided into two groups as the experimental and the control group. A pre-test and post-test were used. The participants of the experimental group studied English vocabulary electronically through WhatsApp three days a week for six weeks using the jigsaw technique. On the other side, the control group was taught vocabulary of their textbook inside the classroom by traditional methods. The results revealed that using the jigsaw technique based on WhatsApp had a significant role in the vocabulary learning of the students.
\end{abstract}

Keywords: JIGSAW IV, Cooperative Learning, WhatsApp, vocabulary

\section{Introduction}

Cooperative learning is considered one of the most fruitful areas of theory, research and practice in education (Johnson et al., 2000). Tran and Vietnam (2014) showed that there was a big effect of the cooperative learning on the students' academic achievement and knowledge retention compared with the students who used lecture-based teaching. According to Aronson \&Patnoe 1997, Jigsaw technique was developed by Eliot Aronson in 1978 for the first time. They mentioned that Jigsaw is one of the cooperative learning techniques as the lesson is subdivided into different parts of information. The teacher divides the students into groups. Every group takes a part (task) from the whole tasks of the lesson and tries to finish it. The next step requires the students to break out of their 'home' groups to form the 'expert' groups where these students focus on one subtopic, researching and discussing it. Therefore, the students become experts on the subtopic that they have been assigned to. Following their discussion, the students from all of the 'expert' groups must return to the 'home' groups and teach their peers based on their findings and discussions. Eventually, all the members of the 'home' groups will have learnt from each expert group discussion and will have benefitted from each other. Exactly, like a jigsaw puzzle, all the groups should help each other to see the whole picture. The jigsaw classroom, originally developed by Elliot Aronson in 1971 in Austin, Texas, was considered effective in increasing positive educational outcomes. Alshammari (2015) proved that there was a positive effect of jigsaw strategy on the students' understanding of the content than the students who received a traditional teaching method. Also, Azmin (2016) revealed that the students were enjoyable and performed better when they used the jigsaw strategy. The role of digital technologies has become clear in the education environment and it has been a basic part of education worldwide. Language education has been at the forefront of technological development and new media are incorporated into acquisition curricula since the start of digital media (Benjamin \& Houssouba, 2015). Language education within the 21 st century has been influenced by new good phone technologies and today's learners have a large vary of digital choices from that they choose their academic contents. Academic technology applications are shown to be effective in student learning outcomes (Schmid et al., 2014). Accordingly, Alsaleem, (2014) using mobile messaging applications among students has proved remarkable progress in learning different language skills and sub-skills like vocabulary, grammar, and reading. Also, Dong, (2004) says that adult students feel with boredom during spending long hours in classrooms to learn English. Consequently, the researcher claims that feeling is available among EFL Arab learners so he thinks that mobile learning applications may be an interesting solution in learning English language skills. This study aimed to explore whether the jigsaw IV technique based on "WhatsApp" had any significant effects on improving Arab EFL learners' vocabulary knowledge. 


\section{Objective of the Study}

The objective of this study was to examine whether or not an appropriate implementation of the Jigsaw IV strategy as a cooperative learning Technique in line with WhatsApp could improve the Participants' vocabularies in the experimental group.

\section{Hypotheses of the Study}

Based on the research objective, the following hypotheses were devised:

1: There is no significant difference between the mean scores of the experimental and control groups on English vocabulary post-test.

Ha2: There is no significant difference between the mean scores of the experimental group on English vocabulary preposttest.

\section{Literature Review}

\subsection{JIGSAW IV Technique}

Cooperative learning is known as the most important active learning technique by grouping students together to accomplish both individual and group learning goals. It has many variants, such as the general cooperative learning model, jigsaw model, and graffiti model. Many benefits of cooperative learning can help in language teaching and learning. From those benefits, cooperative learning gives learners the opportunity to construct their own knowledge and it is the basic frame of communicative approaches. (Apple 2006). Gomleksz (2007) designed a study to see the effect of cooperative learning teaching methods on English language learners against the traditional teacher-centered whole class teaching method. He said that the students in the treatment group who were taught through cooperating learning outperformed the students in the control group who were taught through the traditional whole-class method. The difference between both the groups revealed the effectiveness of cooperative learning methods regarding English language learning.

Jigsaw IV is one of the jigsaw techniques that was developed by Holliday in the late 1990s. However it has the same main forms of the other jigsaw techniques, there are also some differences that distinguish this technique from the others. Many studies of the jigsaw technique proved that it has a positive effect on students' performances in English language skills. Meyers, (1997) claimed that the jigsaw method has many classroom benefits. Sahin (2010) used the Jigsaw II technique and proved a clear improvement in students' academic achievement and attitudes towards a written expression course. Moreover, Whicker, Bol\& Nunnery (1997) investigated that the participants' responses in cooperative learning techniques were likeable. In another side, Ghaith (2001) investigated that learners with lowachievers are satisfied with working in small groups. Moreover, the learners' writings in groups are better than the ones written individually. (Englert, Berry, \&Dunsmore, 2001). Additionally, Arslan (2011) proved that using Jigsaw IV increased students 'self-efficacy beliefs. Moreover, Topsakal,2010 mentioned that students' attitudes towards courses increased by cooperative learning.

Burston (2014) also indicated that 75\% of all MALL applications (apps) concentrate on in-person learning as opposed to cooperative learning apps. Andujar, (2016) added that limited mobile apps are also distinguished as being helpful for collaboration; one famous app is WhatsApp. There are also a number of studies on vocabulary learning via collaborative interaction. One of these studies is Huong (2006) in Vietnam. Huong (2006) investigated learning vocabulary in collaborative groups at a university. The results showed that learning vocabulary was affected by group work. Newton (2001) investigated vocabulary learning through communication tasks. One of the options was cooperative learning in pre-task. Students looked for the meaning of the words in dictionary corporately. The finding showed that cooperative learning helped to improve the vocabulary learning process in pre-task.

\subsection{WhatsApp in foreign language education}

The activity theory is the basic frame work for WhatsApp. This theory encourages learners to share knowledge with their classmates in online communities. Using ICT tools in general and mobile devices in particular can increase cooperation learning strategies among online learners. In addition to, Başoğlu (2010) proved that the users of mobile application could recall the words better than the ones who used traditional methods. Chen (2008) showed that the EFL learners who used mobile phone applications in learning English vocabulary are satisfied and enjoyable. Also, Stockwell (2007) mentioned that the possibility of using mobile applications had a positive effect on the learners' vocabulary knowledge. Moreover, Abdul Fattah, (2015) proved the positive effectiveness of using WhatsApp Messenger in enhancing writing skills among Saudi Arabian college students. In the same way, Bataineh, Al-Hamad, \& Al-Jamal (2018) investigated the impact of WhatsApp on Jordanian students' writing performance. They reported a remarkable improvement on the students' writing skills. 
The present study will answer the following main research question: RQ. Does jigsaw IV technique based on "WhatsApp" have a significant role in enhancing English vocabulary among EFL English-Major Students?

\section{Methodology}

\subsection{Research Design}

The researcher employed a quasi-experimental research design as he designed a pre-post test comparison. In this design, one group received treatment while the other did not receive the involvement. The design employing comparison groups enabled the researcher to compare the treatment effects between the control and experimental groups.

\subsection{Participants of the Study}

Sixty English major university students were randomly selected to share in this study (thirty students in the control and thirty in the experimental groups). The participants are English major students in level two. This study continued for three months (from February 2019 to May 2019). The total students were divided into 2 classes. Every class consisted of 30 students. They were all homogeneous. The members of the experimental group were divided into six groups each consists of five students. Every member had a role and a responsibility in his group. All the members of the group can exchange and discuss their ideas.

\section{Instruments}

The researcher used, in this study, two instruments. They were pre-test and post-test. The aim of the present test was to test the EFL major students 'proficiency in English vocabulary. The test was one part as it was named vocabulary. It consisted of 30 multiple-choice items. The test was designed according to the table of specifications. Also, the time is suitable and the instructions of the test are clear. The researcher administered the test to 15 students similar to the basic participants of the study to recognize the possible mistakes and ensure the reliability of the test. To appraise the reliability of the test, the researcher used Cranach's formula of reliability measure as it was 0.73 . This result is a reasonably high index of reliability. The same pre-test was used as a post-test except for some arrangements of the options.

\section{Findings}

\section{Treatment}

The researcher asked the students of the experimental group to install WhatsApp on their cell phones, tablets or laptops. The participants received vocabulary electronically instructions for six weeks. The students of the experimental group were the participants of the same WhatsApp chat group. The related different videos and pictures were sent to the participants. These videos and pictures could help the students to identify the new vocabulary and their pronunciations. Through WhatsApp, the students could identify the new words' synonyms, antonyms, and definitions. Also, the application includes many drills to practice and different assignments to do. Additionally, the researcher designed three stages. The first stage is named a pre-teaching stage as the information was provided for the students. The second stage is named a teaching stage as the students were asked to use the application to learn new vocabulary. The third stage is named a post-teaching stage as the students' vocabulary performance was measured by post-test.

\section{Data Collection and Analysis Procedures}

The researcher collected the data of the current study through the quantitative form. All the selected participants (the control and the experimental groups) did the pre-test to identify their levels of vocabulary knowledge. While the students of the control group were studying the vocabulary in their textbooks by the traditional method (using jigsaw without WhatsApp) in the college, the students of the experimental group installed WhatsApp and studied the selected vocabulary using jigsaw via WhatsApp. In this study, the researcher used an independent-sample t-test.

\section{Results and Discussion}

The purpose of this study was to investigate the role of jigsaw IV technique based on "WhatsApp" in learning English vocabulary. According to the findings of the study, the experimental group students who used jigsaw IV through WhatsApp had a better performance than the control group students in the achievement test. In this study, firstly it is clear that jigsaw IV based on WhatsApp has a significant effect on learning English vocabulary when it is compared to traditional learning methods. Through the obtained scores of both experimental and control groups, it can be concluded that the experimental group is more successful than the other one. This is supported To answer the main research question" Does jigsaw IV technique based on "WhatsApp" has a significant role in enhancing English vocabulary among EFL Major Students?", the researcher used Paired-Sample T-test as the following tables show. 
Table (1) shows the differences between pre-test and post-test in the experimental group using Paired-Sample T test

\begin{tabular}{|c|c|c|c|}
\hline Group & Mean & N & Std.Deviation \\
\hline Pretest & 12.4 & 25 & 2.36 \\
\hline Posttest & 16.5 & 25 & 1.42 \\
\hline
\end{tabular}

Table 1 shows that the mean scores of post-test (16.5) is higher than the mean score of pre-test (12.4). It means that there is an improvement in students' English vocabulary. Moreover, the score of Std. Deviation of pre-test (2.36) is higher than Std. Deviation of post-test (1.42). The results of the present research are aligned with previous studies on the effectiveness of Jigsaw learning strategy in improving students' achievement (Abed et al., 2019 and Azmin, 2016), developing students' conceptual knowledge and understanding, and in enhancing students' attitude (Yimer\&Feza, 2019).

Table (2) shows the differences between pre-test and post-test with the control group students using Paired-Sample T test

\begin{tabular}{|c|c|c|c|}
\hline Group & Mean & N & Std. Deviation \\
\hline Pretest & 13.000 & 25 & 1.472 \\
\hline Posttest & 13.700 & 25 & 1.384 \\
\hline
\end{tabular}

Table 2 shows that the mean scores of the post-test (13.700) are near from the mean score of pre-test (13.000). It means that there was no clear difference between the pre-posttest and the reason was the control group did not expose the experiment.

Table (3) shows the differences between the mean scores of the post-test for the experimental group and the mean scores of the post-test for the control group using the Independent-Sample T test.

\begin{tabular}{|c|c|c|c|}
\hline Group & Mean & N & Std. Deviation \\
\hline Experimental & 16.88 & 25 & 1.24 \\
\hline Control & 12.16 & 25 & 1.28 \\
\hline
\end{tabular}

Table 3 shows that the mean scores of post-test for the experimental group (16.88) is higher than the mean score of post-test for the control group (12.16). It means that the experimental group performed well in the posttest comparing with the control group.

In light of the obtained findings from the study, it has been concluded that the jigsaw IV technique based on WhatsApp is more effective than traditional teaching methods in foreign language teaching, specifically vocabulary. Also, it has been concluded that the jigsaw IV technique based on WhatsApp is useful and effective to increase the academic achievements of students and makes teaching and learning process become interesting and enjoyable. It was proved by the observation and interview. The study is also limited to the vocabulary sub-learning area of an English course. It can be applied to other sub-learning areas of English courses. At the same time, it is also possible to perform it in other courses.

\section{Conclusion}

Based on the findings of the present study, the researcher can conclude that Jigsaw IV based on "WhatsApp" had a positive role in enhancing English Vocabulary among EFL English-Major students. These results help EFL teachers make use of co-operative learning (jigsaw IV) based Mobile applications (WhatsApp) for providing real communicative situations for EFL learners as they can increase their vocabulary knowledge. Moreover, The findings of this study revealed that the field of language learning and teaching needs more different studies based on WhatsApp . Future studies can be carried out to identify the effect of jigsaw IV based on technological applications on large samples of learners with different age levels.

\section{References}

Abdul Fattah, S.F.E.S (2015). The effectiveness of using WhatsApp messenger as one of mobile learning techniques to develop students' writing skills.Journal of Education and Practice.6(32), 115- 127.

Abed, A. Z., Sameer, S. A., Kasim, M. A., \& Othman, A. T. (2019).Predicting Effect Implementing the Jigsaw Strategy on the Academic Achievement of Students in Mathematics Classes.International Electronic Journal of Mathematics Education, 15(1), em0558.

Alsaleem, B. I. A. (2014). The Effect of "WhatsApp" electronic dialogue journaling on improving writing vocabulary word choice and voice of EFL undergraduate Saudi students.21st Century Academic Forum Conference at Harvard Boston, MA U.S.A. Official Conference Proceedings. http://www.21 caf.org/uploads/1/3/5/2/13527682/alsaleem-hrd- conference_proceedings.pdf. 
Alshammari, N. M. (2015). Effects of cooperative learning on academic performance of college students in Saudi Arabia.Unpublished Master Thesis, State University of New York at Fredonia, Fredonia, New York.

Andujar, A. ( 2016). Benefits of mobile instant messaging to develop ESL writing.System, 62, 63- 76.

Apple, M.T. (2006). Language Learning Theories and Cooperative Learning Techniques in the EFL Classroom.Doshisha Studies in Language and Culture, 9(2), 277-301.

Aronson, E., \&Patnoe, S. (1997). Cooperation in the classroom: The jigsaw method. New York: Longman.

Arslan, A. (2011).The Effect of jigsaw iIV on gains, self efficacy belief and self regulation skill. ZKÜ Journal of Social Sciences, 7(13), 369-385.

Azmin, N. H. (2016). Effect of the Jigsaw-Based Cooperative Learning Method on Student Performance in the General Certificate of Education Advanced-Level Psychology: An Exploratory Brunei Case Study. International Education Studies, 9(1), 91-106.

Başoğlu, E. B. (2010). A comparison of undergraduate students' English vocabulary learning: Using mobile phones and flashcards. Educational Technology, 9(3), 1-7.

Bataineh, R. F., Al-Hamad, R. F., and Al-Jamal, D. A. (April 2018). Gender and EFL writing:Does WhatsApp make a difference? Teaching English with Technology, 18(2), 21-33.

Benjamin, M., \&Houssouba, M. (2015).Looking forward by looking back: Applying lessons from 20 years of African language technology.Presented at the 7th Language \& Technology Conference: Human Language Technologies as a Challenge for Computer Science and Linguistics.

Burston, J.( 2014). The reality of MALL: still on the fringes. CALICO Journal, 31, 103- 125.

Chen, X.- B.( 2013). Tablets for informal language learning: student usage and attitudes. Language Learning \& Technology, 17, 20-36.

Dong, Y. R. (2004).Teaching language and content to linguistically and culturally diverse student.Greenwich, CT: Information Age Publishing.

Englert, C. S., Berry, R., \&Dunsmore, K.(2001). A case study of the apprenticeship process; another perspective on the apprentice and the scaffolding metaphor [Electronic version]. Journal of Learning Disabilities, 34 (2), 152-171.

Ghaith, G. M. (2001). Learners' perceptions of their STAD cooperative experience. System, 29(2), 289-301.

Gomleksz, M. N. (2007). Effectiveness of cooperative learning (jigsa 11) method in teaching English as a foreign language to engineering students (case of Firat University, Turkey), European Journal of Engineering Education, 32(5), 613-625.

Hazaea, A., \&Alzubi, A.( 2016). The effectiveness of using mobile on EFL learners' reading practices in Narjan University. English Language Teaching, 9, 8-21.

Holliday, D. C. (2002). Jigsaw IV: Using student/teacher concerns to improve jigsaw III. ERIC ED 465687.

Huong, L. P. (2006). Learning Vocabulary in Group work in Vietnam. RELC, 37(1), 105-121.

Johnson, D. W., Johnson, R. T., \&Stanne, M. B. (2000). Cooperative learning methods: a meta-analysis. (Retrieved on October 11, 2013).

Meyers, S. A. (1997). Increasing student participation and productivity in small-group activities for psychology classes. Teaching of Psychology, 24 (4), 105-115.

Newton, J. (2001). Options for Vocabulary Learning through Communication Tasks. ELT Journal, 55 (1), 30-37.

Sahin, A. (2010). Effects of Jigsaw III technique on achievement in written expression.Asia Pacific Education Review, 12(3), 427-435. http://dx.doi.org/10.1007/s12564-010-9135-8

Schmid, R. F., Bernard, R. M., Borokhovski, E., Tamim, R. M., Abrami, P. C., Surkes, M. A., ...Woods, J. (2014). The effects of technology use in postsecondary education: A meta-analysis of classroom applications. Computers \& Education, 72, 271-291.

Stockwell, G. (2007). A review of technology choice for teaching language skills and areas in the CALL literature.ReCALL, 19(2), 105-120. http://dx.doi.org/10.1017/S0958344007000225

Tran, V. D. \& Vietnam, A. G. (2014). The effects of cooperative learning on the academic achievement and knowledge retention. International Journal of Higher Education, 3(2), 131-140. Available at http://dx.doi.org/10.5430/ijhe.v3n2p131-140

Topsakal, Ü. U. (2010).The Effectiveness of Cooperative Learning On Teaching 8th Class Unit_Substance and Energy for Living Things. Journal of Ahi Evran University Journal of Faculty of Education, 11(1), 91-104

Whicker, K. M., Bol, L., \&Nunerery, J. A. (1997).Cooperative learning in the Secondary Mathematics Classroom. The Journal of Educational Research, 91(1), 42-48. http://dx.doi.org/10.1080/00220679709597519

Yimer, S. T., \&Feza, N. N. (2019). Learners' Conceptual Knowledge Development and Attitudinal Change towards Calculus Using Jigsaw Co-operative Learning Strategy Integrated with GeoGebra. International Electronic Journal of Mathematics Education, 15(1), em0554. 